\title{
Claes-Göran Holmberg och Jan Svensson (red.) Mediekulturer: Hybrider och förvandlingar Carlssons
}

\section{Av Mikael Askander}

\author{
Länk till presentation av Mikael Askander
}

I talet om samtiden och våra dagars samhälle handlar det i allt högre grad om medialiseringen av allting: vi lever i en tid då medier av allehanda slag styr såväl våra vardagsliv, som de mer övergripande politiska skeendena. Att beskriva och analysera detta medialiserade tidevarv och de många därtill hörande fenomenen måste betraktas som både viktigt och nödvändigt. Därför tycker jag också att Claes-Göran Holmbergs och Jan Svenssons antologi, Mediekulturer: Hybrider och förvandlingar (2004) känns direkt angelägen. Detta inte minst för att den är så sprakande rik på infallsvinklar och idéer att man närmast känner sig överväldigad som läsare. och sannolikt lämpar sig Mediekulturer mindre för sträckläsning och mer som utportionerad läsupplevelse, en artikel eller essä åt gången är vad man mäktar med. Och det rör sig tveklöst om intressant, spännande och bildande läsning.

I det inledande förordet förklarar redaktörerna upplägget; bokens många vitt skilda ämnen och förhållningssätt är satta i spel kring ett antal viktiga frågeställningar. Dessa är: Genomlysning eller mörkläggning? Sken eller verklighet? Personligt eller distanserat? Fördjupning eller förytligande? Gammalt eller nytt? Flertalet av texterna i boken tar itu med dessa frågor, även om tyngdpunkten oftast hamnar på olika delar av fältet. Den i mina ögon kanske viktigaste texten i volymen är också den som tar det mest omfattande greppet, och berör det mesta som har med medialiseringen och dess samhälleliga funktioner och konsekvenser att göra: Peter Dahlgrens "medborgarkultur i samtidens mediemiljö". Här för Dahlgren fram flera centrala frågor rörande demokratins framtidsutsikter i en värld präglad av det faktum att allt mer av diskussionerna om stort och smått äger rum i de moderna medieteknologiernas labyrinter.

Vidare finner jag den i undertiteln och förordet explicit uttalade inriktningen mot hybridisering och transformation träffande. Flertalet av skribenternas alster lyckas som en mångfacetterad helhet övertyga mig om att det är just detta som sakernas tillstånd handlar om i dessa sammanhang. Hybriderna är alltså de många intermediala fenomen i vilka olika konst- och medieuttryck blandas, integreras (till exempel ljud, bild, text på Internet), medan transformationerna, förvandlingarna, utgörs av berättelsers och utsagors förflyttningar från en konstform eller diskurs till en annan, till exempel filmatisering.

Om man så försöker närma sig och beskriva de enskilda texterna i Mediekulturer blir det med nödvändighet fråga om en övergripande och ganska kortfattad sammanställning. Jag konstaterar att ett flertal av textförfattarna har sina rötter i litteraturvetenskapen. Detta är inte konstigt, dels är redaktör Claes-Göran Holmberg själv litteraturvetare (och pressvetare), dels har litteraturvetenskapen kommit att bli den enskilda ämnesdisciplin där just intermedialitetsforskningen haft och har sin starkaste utveckling, i tolknings- och analyspraktiken såväl som i teoridiskussionerna.

Helen Andersson är verksam som forskarassistent vid Centrum för teologi och religionsvetenskap i Lund. Hon är också författare till bokens första bidrag, "Litteratur som virtuell verklighet och drömvision: exemplet Dykungens dotter". Andersson genomför en romananalys av Birgitta Trotzigs Dykungens dotter. Det är en på många sätt välformulerad 
och skarpögd läsning av Trotzigs roman, även om jag i viss mån också får ett intryck av att Andersson ägnar sig mer åt en relativt traditionell litteraturvetenskaplig textanalys, än en tydlig diskussion av textens intermediala karaktär och relation till andra mediers verk, genrer och uttryck. Jag hade - till exempel - gärna sett mer av en utvecklad redogörelse för ekfrasernas funktion i romanen. Anderssons koppling mellan Dykungens dotter och romantikens estetik känns annars mitt i prick. Och jag skriver helt under på Anderssons reflektioner om skönlitterära texter som virtuella världar. Virtual Reality, Cyberspace, med mera, är kanske inte i grunden någon särskilt ny estetisk upplevelse för människan; för har vi inte egentligen i alla tider rört oss i virtuella världar - i vår läsning av och vårt lyssnande till eller vårt betraktande av berättelser och fiktion i såväl litteraturens som filmens och TV-seriernas världar?

Det längsta bidraget utgörs av Johan Elmfeldts essä, "Verklighet och illusion". Elmfeldt ställer i centrum för sin infallsrika text frågor om huruvida gränserna mellan verklighet och fiktion är på väg att lösas upp (eller inte) i de nyare medieteknologiernas diskurser, inte minst beträffande Virtual Reality och så kallade hypertexter, det vill säga texter med länkar som leder till andra texter eller textfält. Elmfeldt diskuterar också hur dessa frågor har tematiserats i bland annat skönlitteratur, på film och i TV-serier.

Lennart Nyberg redogör för hiphopkulturens texter, och sätter den amerikanske rapartisten Eminems lyrik i fokus för sin studie, "Eminems Gothic: raptexten som berättelse, rollspel och självbekännelse". Bland annat visar Nyberg hur Eminem likt många andra hiphopare förhåller sig till andra genrer och medierade uttryck, och att det här handlar om en teatraliserad, dramatiserad iscensättning av dels olika självbiografiska aspekter, dels en samhällskritisk hållning. Eminem skiljer dock ut sig från mycken annan hiphop, genom att i så hög grad som han gör i sina texter och framträdanden referera till och använda sig av skräckgenrerna inom populärkulturen.

Överhuvudtaget slås man av att flera av bidragen i Mediekulturer på ett eller annat sätt sysslar med just det gotiska, skräckkulturer av olika slag. Detta gäller även Yvonne Lefflers eleganta genomgång av området, där hon inte minst pekar på skillnader mellan filmens och äldre litterära texters olika genrespecifika mekanismer. Framför allt visa Leffler på hur perspektiven i skräckfilmer skiftar från hjälte till monster, och därmed problematiserar identifikationsaspekten för betraktaren. I 1700- och 1800-talens litteratur var berättarpositionen stabilare; läsaren kunde upprätta en distans mellan sig själv och verket och uppleva en känsla av säkerhet inför fiktionens gestaltade hemskheter.

Skräckfiktionen tas också upp till behandling av Claes-Göran Holmberg, i hans lika vindlande som lärorika resonemang om Draculamytens förvandlingar från en mediediskurs till en annan. Holmberg hinner med att gå igenom Dracula på film, i skönlitteratur, som dataspel och seriemagasin.

En annan av de litteraturvetenskapligt orienterade forskare som representeras i volymen är Magnus Persson. Han diskuterar i sitt bidrag relationen mellan "högt" och "lågt", här främst med avseende på hur mer "finlitterärt" etablerade författare på olika sätt har tagit sig an sådant som har betraktats som låg- eller masskultur. Persson utgår från 1960-talets svenska litterära offentlighet, konstaterar att "inflytande från masskulturen finns där" men frågar sig också: "varför, och hur kan den tolkas?" Persson siktar in sig på författarnas hantering och gestaltning av det framväxande medielandskapet, men även dess inflytande på det litterära verkets form diskuteras. Två huvudvägar tycks enligt Persson löpa ut från 1960-talets författare i deras relation till medier och masskultur: dels konkretisternas och de avantgardistiska romanförfattarnas formexperimenterande, dels realisternas och de samhällskritiska författarnas avromantisering av litteraturen och deras sociala patos (den "vanliga" människans vardagsliv hamnar i centrum). Persson pekar sedan ut ett antal olika exempel på skönlitterära verk och deras gestaltningar av masskulturen och det medialiserade samhället de senaste decennierna.

I princip är alla bidragen i Mediekulturer mycket läsvärda, för att inte säga tänkvärda. Ett par exempel till kan i all korthet omnämnas, inte minst för att de breddar materialet och 
infallsvinklarna i boken rejält. Henrik Rahms "Att märkas i mediabruset: hybridformer och genrer i reklamdiskurs". Rahm undersöker direktreklam (som vi får hem i våra brevlådor) och annonsmaterial i dagspressen. Texten formar sig till en kartläggning av reklamens relation till och beroende av andra text- och uttrycksformer, med avseende på hybrider eller sammansmältningar av text och bild. Rahm utskiljer bland annat fem återkommande kategorier i reklamen: "fråga-svar", "faktasamling", "intervjun", "det personliga exemplet" och "det föregivet personliga brevet". En undersökning som Rahms, och fortsatt forskning om dessa frågor av det här slaget, framstår som synnerligen centralt med tanke på hur mycket reklam vi dagligen bombarderas med. Att skönja mönster och blottlägga syften och mekanismer torde förstås som grundläggande i den viktiga kritiska blick som varje medborgare bör utrusta sig med, med tanke på såväl försvarandet av den personliga integriteten, som för en fungerande demokrati där alla kan "vara med i matchen" på bästa sätt.

En annan intressant upptäckt står att finna i Jana Holsanovas och Kenneth Holmqvists artikel om nyhetsläsning på Internet, "Med blick på nätnyheter . . . Ögonrörelsestudier av läsning i nätbaserade tidningar". Studien är gjord vid Avdelningen för kognitionsforskning vid Lunds universitet. Och bland mycket annat skall här bara påpekas det mest tankeväckande: nämligen att författarna menar att läsare generellt sett läser tidningsartiklar publicerade på Internet noggrannare och utförligare jämfört med läsningen av texter i papperstidningar. Holsanova och Holmqvist skriver att "[e]fter att läsarna bestämt sig att klicka på en länk/ingress brukar de också djupläsa artikeln (sannolikheten är $90 \%$ ). Det motstånd som måste övervinnas kan också tänkas vara skälet till att nätläsningen är 'smal': läsaren vill inte byta artikel". Är inte detta en smula uppseendeväckande? Nog går de flesta av oss omkring med föreställningen att papperstidningen är den "riktiga" tidningen, den man ägnar mest uppmärksamhet, medan surfandet på nätet har uppfattats som mer fragmentariserat och stressat. Åtminstone undertecknad är förvånad - och fascinerad av detta resultat!

Som synes är spretigheten eller bredden stor i Mediekulturer. Och det ska inte ses som något negativt; snarare handlar det om en uppfriskande och ögonöppnande spretighet, kongenial med innehållets kalejdoskopiska mångfald. I något enstaka svagt ögonblick i mitt umgänge med Holmbergs och Svenssons antologi slås jag av en lätt tvekan. Jag är på väg att över mina läppar släpa ett lite frågande "och?". Vad jag syftar på är helt enkelt om Mediekulturer verkligen har någon relevans. Behöver vi ännu en bok om det samtida medielandskapet? Jo, jag tror det, särskilt när resultatet blir så intressant och problematiserat som i detta fall. Och som jag skrev inledningsvis: Det är en bok som känns angelägen och viktig, och man kan tillfoga: i bästa mening stimulerande för fortsatta viktiga diskussioner.

(C) Mikael Askander 